\title{
Utilization of horse beans by growing finishing pigs after tryptophan supplementation
}

\author{
Y. HENRY, 1). BOURDON, I'. H. DIÉE, Janine JUNG \\ Station de Recherches sur l' Élevage des porcs, I. N. R. A., C. N. R. Z., \\ r8350 Jouy en Josas
}

Utilization of whole horse-beans in growing-finishing pig diets was studied in two experiments including respectively $4^{8}$ animals in collective pens ( 2 treatments) and 84 animals in individual pens ( 7 treatments). The aim of these experiments realized between 20 and $100 \mathrm{~kg}$ live weight was to examine the interest of supplementing a diet based on maize with free tryptophan in presence of niacine or not, in the case of partial or almost total replaccment of soyabean meal by horse-beans.

For the growing period, the results obtained showed that introduction of 15 or 30 p. Ioo horse-beans into the diet caused a decrease in the daily mean gain of 2 and 6 p. roo, respectively, while the feed conversion ratio increased by 3 and 9 p. roo.

Tryptophan supplementation ( 0.03 p. roo during the growing period, $0.02 \mathrm{p}$. Ioo during the finishing period) at the highest level of horse-bean incorporation ( $30 \mathrm{p} .100)$ in a diet containing o.I 3 p. Ioo tryptophan during growth and o.I I p. too during finishing, brought about an improvement of growth rate and feed efficiency of 6-7 p. 100 , particularly marked when niacine was absent from the mixture of vitamins, whereas the carcasses tended to be leaner. The performances obtained only slightly differed from those recorded with the control diet (maize + soyabean meal). At the level of I 5 p. Ioo horse beans, the supply of supplementary tryptophan (0.02 p. I00), over 0.16 p. 1 oo during growth, only caused a slightly favourable but non significant effect ( 2 p. Ioo) and only in the females.

Variation in the blood level of free amino acids (accumulation of lysine and threonine relatively to the sum of essential amino acids, in presence of tryptophan deficiency) confirms, to a great extent, the results observed on growth and feed efficiency.

In conclusion, supplementation of horse beans with tryptophan in growing pig diets cons tributes to removing some of the difficulties arising from a massive incorporation of this legume into the diet. Owing to this it is possible to replace almost all soyabean proteins by horse bean proteins, at an incorporation level of $30 \mathrm{p}$. Ioo.

\section{Comparative study concerning the use of peas and horse-beans lyy growing pigs}

\author{
D. BOLRDON, J.-M. PLERZ
}

Station de Recherches sur l' lilevage des porcs, I. N. R. A., C. N.R.Z., 78350 Jouy en Josas

This study was made on growing finishing pigs in order to compare the use of a productive variety of winter peas, $A 86,(24.2 \mathrm{p}$. Ioo crude protein in dry matter $)$ and that of variety of horse-beans, AscotT, $(28.9$ p. roo crude protein in dry matter), as supplementary source 
of protein. The legume seeds were introduced at levels of $I_{5}$ and $30 \mathrm{p}$. Ioo into diets based on maize ( 16 p. I oo crude protein and 3300 kcal digestible energy $/ \mathrm{kg}$ ) and rebalanced with tryptophan to satisfy the requirements (O.I5 p. IOo) by addition of soyabean meal.

Sixty Large White pigs were divided into 5 groups of 12 animals 6 castrated males and 6 females) according to the following experimental scheme :

- Group I : control diet : maize (73 p. Ioo) soyabean meal (2 I p. Ioo).

- Group 2 : maize $(65$ p. roo) peas ( 15 p. Ioo) soyabean meal (1+ p. 1001.

-- Group 3 : maize (53 p. Ioo) peas (30 p. гоo) soyabean meal ( I p. гоo).

- Group $t$ : maize $(67$ p. Ioo) horse beans ( 5 p. Ioo) soyabcan meal (I 2 p. 100).

- Ciroup 5 : maize $(58 \mathrm{p}$. 100) horse beans (30 p. I00) soyabean meal (6 p. 100).

The pigs, kept in individual pens, received the feed in form of pellets in one only meal per day, according to a feeding schedule depending on live weight. The same diet was offered during the overall fattening period from $2+$ to roo $\mathrm{kg}$ live weight.

Under our experimental conditions, introluction of peas or horse beans into the diets in a proportion of $\mathrm{r}_{5}$ and $30 \mathrm{p}$. Ioo respectively, led to obtention of high performances as compared to those recorcled with the control diet (maize-soyabean meal) : growth rate $(\mathrm{g} / \mathrm{d})$ and feed conversion ratio (kg air dry feecl $/ \mathrm{kg}$ gain), respectivcly: group I : 692, 3.08 - group $2: 685,3.1$ I - group $3: 678,3.17$ - group $+: 684,3.12-$ group $5: 687,3.08$ from $2+$ to 1 oo $\mathrm{kg}$ live weight. Likewise, for all body composition criteria, the statistical analysis of the results dicl not show any significant difference between the groups.

The findings of this study show that the use of peas and horse beans shall not only be considered in terms of total replacement of soyabean meal as the legumes also substitute for large fraction of cereals. Besides, the presence of soyabean meal appeared to be necessary, notably as a source of tryptophan; this supplementation leading to an optimun valorization of the legumes. Inder these conditions, peas and horse beans can be used in pig diets at an incorporation level of I 5 and esen $30 \mathrm{p}$. roo during the whole growing period.

\title{
Nutritice value of animal by products (keratin, gelatin) for growing-finishing pigs
}

\author{
A. RÉRAT, J. BOURDON \\ Laboratoire de Physiologie de la Nutrition. \\ Station de Recherches sur l'Elevago des porcs, I. N.R. A., C.N.R.Z., \\ 78350 Jouy on Josas
}

This study was made in order to estimate the nutritive value of keratin (horn meal) and gelatin (pig skin meal) as partial replacers of soyabean meal in cereal based diets.

The horn meal used was a product (lried in hot air $\left(\mathrm{r} 35^{-}-4^{\circ}{ }^{\circ} \mathrm{C}\right)$ for 24 hours, ground and sifted. I'art of the product was used in this form, the rest subjected to ultragrinding leading to reduction of the particle size from 320 to $80 \mu$.

The gelatin studicd came from pig skin meal subjected to various treatments (acidification, cooking). The chemical and amino acid composition of these products is reported.

For the "keratin" trials, the experimental schedule included 3 groups of $\mathrm{I}_{4}$ Large. White pigs 7 castrated males, 7 females) subjected to lot trials between 30 and Ioo $\mathrm{kgr}$ live weight and 3 groups of + growing castrated males $(30-35 \mathrm{~kg})$ for studying digestibility. The diets used were the following : 